\title{
Specific Lymphocyte Sensitization in Cancer: Is There a Common Antigen in Human Malignant Neoplasia?
}

\author{
E. A. CASPARY, E. J. FIELD
}

British Medical fournal, 1971, 2, 613-617

\begin{abstract}
Summary
From human cancer tissue a basic protein can be extracted by the method which yields encephalitogenic factor when applied to human brain. This tumour basic protein (obtained from several different neoplasms) acts as an antigen in the cytopherometric test for malignant neoplasia and in general gives higher results than does brain basic protein. The reverse is true when degenerative disease of the nervous system is studied. The basic protein extractable from brain and from tumours thus has some degree of specificity probably referable to its amino-acid sequence.
\end{abstract}

\section{Introduction}

It has recently been claimed (Field and Caspary, 1970) that lymphocytes from patients with malignant neoplasia are sensitized to a basic protein derived from human brain (encephalitogenic factor; E.F.) (Caspary and Field, 1965). We interpreted this to mean that the antigenic determinant of E.F. made its appearance on the surface of cells which had undergone malignant change from any cause. It should be possible therefore to extract E.F. (or antigenically similar material) from malignant tumour tissue. The present work reports such attempts and compares the antigenicity of such tumour basic protein with that made from human brain. While basic protein derived from a malignant growth is a better antigen than E.F. in testing for tumours, the reverse is true when lymphocytes are sensitized to nervous tissue protein as the result of nervous tissue breakdown.

\section{Patients and Methods}

Lymphocytes were isolated from the blood of patients known to be suffering from malignant neoplasia and also from those affected by organic disease of the nervous system as previously described (Field and Caspary, 1970) with saccharated iron and methyl cellulose. E.F. was prepared from human brain by the method of Caspary and Field (1965). In principle it consists of prolonged extraction of lipids from the homogenized tissue with a chloroform-methanol mixture followed by extraction of the defatted residue with hydrochloric acid $(\mathrm{pH}<3.5)$. (In the 1965 preparation $\mathrm{pH}<2.5$ was set as the limit.) Human brain obtained postmortem (usually from fatal injury but not showing gross brain damage) is stripped of membranes, washed in cold saline, and homogenized in a Waring blender at $4^{\circ} \mathrm{C}$. The suspension is washed again in cold saline, spun, resuspended in about 10 volumes of distilled water, and freeze dried. The dried white powder is extracted with 10 volumes of chloroformmethanol mixture $(2: 1)$ for at least half an hour on a mechanical

Medical Research Council, Demyelinating Diseases Unit, Newcastle General Hospital, Newcastle upon Tyne NE4 6BE

E. A. CASPARY, M.SC., Member of Scientific Staff

E. J. FIELD, M.D., M.S., Professor of Experimental Neuropathology shaker. The residue is spun down (600 $\mathrm{g}$ for 10 minutes), the supermate discarded, and the process repeated. The residue is then washed about four to six times in distilled water till the smell of solvent can no longer be detected. This is important.

The residue is then extracted with 10 volumes of $5 \% \mathrm{NaCl}$ (analar) for two to four hours with frequent shaking. The supernate is spun off and the residue extracted with $\mathrm{N} / 50 \mathrm{HCl}$ (10 volumes) (the 1965 procedure used $\mathrm{N} / 100 \mathrm{HCl}$ ) at $20^{\circ} \mathrm{C}$ (room temperature). Extraction is continued with the use of a magnetic stirrer changing the hydrochloric acid at about half-hourly intervals, four times over the space of about three hours. Supernates are kept separately and their $\mathrm{pH}$ is measured. Those with $\mathrm{pH}<3.5$ ( $<2.5$ in the 1965 procedure) are pooled; those with $\mathrm{pH}>3.5$ are discarded. The pooled extracts are cooled to $4^{\circ} \mathrm{C}$ and protein is precipitated by the addition of ammonium sulphate solution (at $4^{\circ} \mathrm{C}$ ) to give a $40 \%$ concentration, the procedure being carried out slowly in the cold room with slow stirring. The precipate is centrifuged off at 2,000 r.p.m. ( $\left.4^{\circ} \mathrm{C}\right)$ for 10 to 15 minutes. The pellet is dissolved in a small volume of distilled water and dialysed through Visking tubing against distilled water at $4^{\circ} \mathrm{C}$ until the external fluid shows no ammonium sulphate (by $\mathrm{BaCl}_{2}$ precipitation). The material inside the Visking tubing may need centrifugation. The clear solution is freeze dried to a white powder. From $25 \mathrm{~g}$ of freeze-dried brain about $250 \mathrm{mg}$ of this powder is obtained and is used in this form as the brain antigen (E.F.) for the cytopherometric test. It has one major band and a number of minor ones when run on polyacrylamide gel, and details of how it may be further "cleaned up"are given by Caspary and Field (1965).

For the preparation of tumour antigens the same method obtains. Specimens are obtained fresh at operation, dissected clear of surrounding tissues, and cut up into pieces before homogenization, which is generally more difficult than with brain. The final yield of basic protein is much smaller-about $1 \mathrm{mg} / \mathrm{g}$ of original wet tumour tissue. Carcinoma of vulva, breast, bronchus, and stomach have served as source materials in this study. On electrophoresis (acrylamide gel) there are four major bands and a number of minor ones.

\section{CYTOPHEROMETRIC TEST}

The cytopherometric method of assessing lymphocyte sensitization has been described elsewhere (Field, Caspary, Hall, and Clark, 1970; Field and Caspary, 1971), it depends in principle on the interaction of sensitized lymphocytes with specific antigen to liberate some material (involving protein synthesis by the lymphocytes (Caspary, 1971)) which has the property of slowing electrophoretic migration of normal macrophages. The latter (obtained from the peritoneum of a normal guinea-pig) are thus used as an indicator system for lymphocyte-antigen interaction.

All measurements are made in medium 199. The mixture put into the electrophoresis chamber consists of $0.5 \times 10^{\circ}$ human lymphocytes with $10^{7}$ macrophages (irradiated to obviate mixed cell reaction as explained previously (Field et al., 1970;

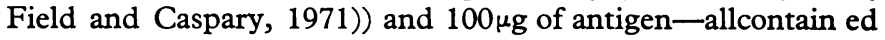
in $3.1 \mathrm{ml}$ of medium 199. The $\mathrm{pH}$ is about 7.2 (indicator is in the medium). 
All measurements are made "blind" in the cytopherometer and the coded specimens later unscrambled (see Tables IV and $V)$. If $t_{c}=$ time of macrophage migration in the presence of human lymphocytes without antigen (control time), and $t_{e}=$ time of migration in the presence of lymphocytes together with antigen, then

$$
\frac{t_{e}-t_{c}}{t_{c}} \times 100
$$

represents the percentage slowing of macrophages induced by the presence of the antigen.

\section{MACROPHAGE MIGRATION CONTROL RATE}

Macrophage migration control rate-that is, in the presence of human lymphocytes without antigen-has been very consistent in all experiments over the last 14 months. Small variations may occur when a new batch of medium 199 is used. The calculation of the percentage change in time of migration means that measurements made on a particular day are referred to the control value found on that day. As typical of the sort of consistency experienced, the following series of control values (in seconds) were recorded between $20^{\circ}$ and 30 November 1970: $6 \cdot 105,6 \cdot 035,6 \cdot 065,6 \cdot 100,6 \cdot 185,6 \cdot 100,6 \cdot 185,6 \cdot 180$, $6 \cdot 085,6 \cdot 095,6 \cdot 145,6 \cdot 190,6 \cdot 140,6 \cdot 125$. Between 7 and 18 January 1971 they were: $6 \cdot 105,6.040,6.050,6 \cdot 140,6 \cdot 145$, $6 \cdot 195,6 \cdot 190,6 \cdot 115,6 \cdot 075,6 \cdot 045,6 \cdot 090,6 \cdot 070,6 \cdot 020,6 \cdot 105$, 6.045 . On only two or three occasions has a value as low as 5.995 been obtained, and then it has tended to remain low with that particular batch of medium 199.

Though the figures given are to three decimal places measurements are in fact made with a stopwatch to the nearest $0.1 \mathrm{sec}$.
Twenty readings ( 10 cells in each direction of the potential difference) are timed. In making readings the observer must fix on cells which are in focus and remain so throughout their transit. If a cell moves out of this layer electrical forces come into operation and influence its migration speed when measured in both directions of the potential difference. If this occurs to an extent greater than $0.6 \mathrm{sec}$ (an arbitrary figure) that cell should be neglected. Turbulence within the observation chamber results in cells "tumbling" and no measurements can be made under these conditions. A typical protocol is set out below (see Tables IV and V). The tube numbers refer to the order in which they were done "blind"- simply as numbered tubes 1 to 18. Remarkably little variation occurs within a set of readings and it is this which allows even relatively small time differences to reach high statistical significance.

A few subjects-mainly laboratory workers-have been studied at intervals of a few weeks with very consistent results. As emphasized previously (Field and Caspary, 1970) everything depends on the machine working well and the patience of the observer (E.A.C.) in perfecting his technique, so that the standard deviation for the migration time of macrophages is of the order of $2 \%$.

The main object in this work was to compare the efficacy as antigen of basic protein extracted from malignant tumours with basic protein (E.F.) from brain. (Benign tumoursfor example fibroadenoma of breast-have not yet been available; preliminary results from normal tissue are different and will be described elsewhere.) This comparison was made both in patients with malignant neoplasia and in those suffering from organic destruction of the nervous system. Attempts were made to "block" the antigenic action of cancer basic protein by serotonin and structurally related drugs as well

TABLE I-Results in Cases of Malignant Disease and Nervous System Disease

\begin{tabular}{|c|c|c|c|c|c|c|c|c|c|c|}
\hline $\begin{array}{l}\text { Case } \\
\text { No. }\end{array}$ & Age & Sex & E.F. & $\begin{array}{l}\text { Epith. } \\
\text { vulva }\end{array}$ & $\begin{array}{c}\text { Ca. } \\
\text { Breast } 1\end{array}$ & $\underset{\text { Breast } 2}{\text { Ca. }}$ & $\begin{array}{c}\text { Ca. } \\
\text { Stomach }\end{array}$ & $\begin{array}{l}\text { Ca. } \\
\text { Lung }\end{array}$ & $\begin{array}{l}\text { Lympho- } \\
\text { sarc. }\end{array}$ & Diagnosis \\
\hline $\begin{array}{r}1 \\
2 \\
3 \\
4 \\
5 \\
6 \\
7 \\
8 \\
9 \\
10 \\
11 \\
12 \\
13 \\
14 \\
15 \\
16 \\
17 \\
18 \\
19 \\
20 \\
21 \\
22 \\
23 \\
24 \\
25 \\
26 \\
27 \\
28 \\
29\end{array}$ & $\begin{array}{l}62 \\
46 \\
43 \\
61 \\
44 \\
55 \\
54 \\
64 \\
63 \\
54 \\
3 ! \\
17 \\
81 \\
67 \\
58 \\
80 \\
66 \\
78 \\
35 \\
47 \\
42 \\
39 \\
47 \\
58 \\
60 \\
40 \\
49 \\
63 \\
55\end{array}$ & 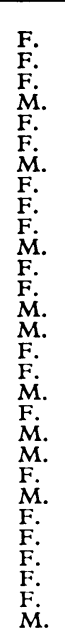 & $\begin{array}{l}16 \cdot 3 \\
20 \cdot 6 \\
16 \cdot 6 \\
17 \cdot 4 \\
16.7 \\
16 \cdot 9 \\
16 \cdot 6 \\
15 \cdot 4 \\
16 \cdot 8 \\
16 \cdot 3 \\
14 \cdot 9 \\
16 \cdot 4 \\
17 \cdot 4 \\
16 \cdot 2 \\
14 \cdot 1 \\
14 \cdot 7 \\
14 \cdot 9 \\
14 \cdot 5 \\
14 \cdot 1 \\
14 \cdot 4 \\
14 \cdot 2 \\
14 \cdot 0 \\
15 \cdot 1 \\
14 \cdot 3 \\
15.7 \\
14 \cdot 3 \\
15 \cdot 2 \\
15.9 \\
15 \cdot 2\end{array}$ & 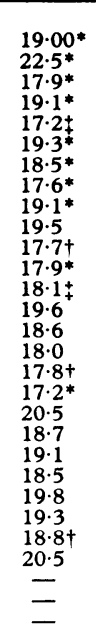 & 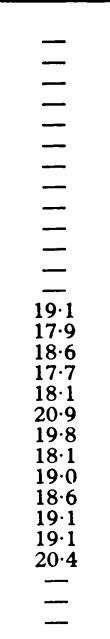 & $\begin{array}{l}= \\
= \\
= \\
= \\
= \\
= \\
= \\
= \\
\overline{19.9} \\
17.5 \\
17.7 \\
17.5 \\
17.8 \\
20.0 \\
18.5 \\
19.1 \\
17.8 \\
20.5 \\
19.1 \\
19.6 \\
19.1 \\
20.5 \\
19.4+ \\
20.3\end{array}$ & $\begin{array}{c}\text { ignant Dise } \\
= \\
= \\
= \\
= \\
= \\
= \\
= \\
= \\
= \\
= \\
= \\
= \\
= \\
= \\
19.3 \\
20 \cdot 2 \\
19.7 \\
19.7\end{array}$ & 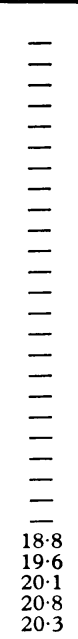 & 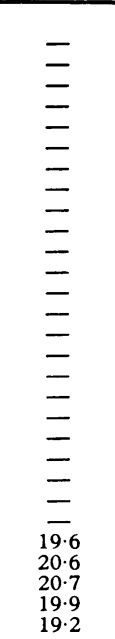 & $\begin{array}{l}\text { Ca. breast } \\
\text { Ca. breast } \\
\text { Hodgkin's disease } \\
\text { Hodgkin's disease, since } 1967 \\
\text { Hodgkin's disease, since } 1968 \\
\text { Ca. cervix, removed } 1963 \\
\text { Ca. bronchus } \\
\text { Ca. uterus } \\
\text { Ca. breast, Oct. 1969; mastectomy Oct. } 1969 \\
\text { Ca. breast, Jan. 1971 } \\
\text { Neuroblastoma } \\
\text { Lymphosarcoma, Aug. 1970, op. Feb. } 1971 \\
\text { ?Ca. bowel } \\
\text { Ca. bronchus } \\
\text { Squamous cell carc.-oropharynx, Nov. } 1970 \\
\text { Ca. breast-mestastases, Dec. } 1967 \\
\text { Ca. pharynx, 1956 } \\
\text { Ca. bronchus, Jan. 1967 } \\
\text { Ca. bronchus, Jan. 1971 } \\
\text { Reticulum-cell sarcoma of pharyngeal wall, Nov. } 1970 \\
\text { Ca. bronchus, Dec. 1970 } \\
\text { Lymphosarcoma } \\
\text { Ca. stomach, Sept. 1969 } \\
\text { Ca. breast, Mar. 1968, mastectomy Mar. } 1968 \\
\text { Ca. stomach, 1970, op. Feb. } 1971 \\
\text { Ca. breast-oophorectomy, } 1969 \text {; op. Feb. } 1971 \\
\text { Follicular lymphoma, Jan. } 1971 \text { (side of neck) } \\
\text { Ca. breast, mastectomy } 8 \text { years } \\
\text { Ca. colon, operation 1 day }\end{array}$ \\
\hline $\begin{array}{l}30 \\
31 \\
32 \\
33\end{array}$ & $\begin{array}{c}33 \\
32 \\
47 \\
14 / 12\end{array}$ & $\begin{array}{l}\text { F. } \\
\text { F. } \\
\text { F. }\end{array}$ & $\begin{array}{l}18 \cdot 2 \\
16 \cdot 7 \\
20 \cdot 3 \\
17 \cdot 2\end{array}$ & $\begin{array}{l}18 \cdot 2^{*} \\
13 \cdot 4 \\
18 \cdot 0^{*} \\
13 \cdot 2\end{array}$ & $\bar{z}$ & $\begin{array}{l}\text { Nerv } \\
\overline{1} \\
12 \cdot 5\end{array}$ & $\begin{array}{l}\text { Systems } \\
\text { 二 } \\
\text { 二 }\end{array}$ & 二 & $=$ & $\begin{array}{l}\text { Demyelinating disease } \\
\text { Paraplegia } \\
\text { Dementia } \\
\text { ?Subacute sclerosing panccephalitis, probably }\end{array}$ \\
\hline $\begin{array}{l}34 \\
35 \\
36 \\
37 \\
38 \\
39 \\
40 \\
41 \\
42 \\
43 \\
44 \\
45 \\
46 \\
47\end{array}$ & $\begin{array}{l}19 \\
54 \\
56 \\
58 \\
42 \\
73 \\
24 \\
57 \\
24 \\
37 \\
44 \\
27 \\
68 \\
38\end{array}$ & $\begin{array}{l}\mathrm{F} . \\
\mathrm{M} . \\
\mathrm{F} . \\
\mathrm{M} . \\
\mathrm{M} . \\
\mathrm{F} . \\
\mathrm{F} . \\
\mathrm{M} . \\
\mathrm{F} . \\
\mathrm{M} . \\
\mathrm{F} . \\
\mathrm{F} \\
\mathrm{M} . \\
\mathrm{F} .\end{array}$ & $\begin{array}{l}20 \cdot 6 \\
18 \cdot 3 \\
20 \cdot 0 \\
19 \cdot 5 \\
17 \cdot 8 \\
22 \cdot 6 \\
20 \cdot 9 \\
18 \cdot 4 \\
22 \cdot 5 \\
20 \cdot 6 \\
23 \cdot 9 \\
20 \cdot 1 \\
22 \cdot 9 \\
18 \cdot 0\end{array}$ & $\begin{array}{c}14.4 \\
15.1 \\
14 \cdot 1 \\
15.1 \\
13.2 \\
13.8 \\
16.8 \\
14 \cdot 1 \\
13.8 \\
= \\
= \\
14 \cdot 0 \\
14 \cdot 1\end{array}$ & $\begin{array}{l}14.2 \\
14.8 \\
14.7 \\
15.2 \\
13.0 \\
14.8 \\
15.6 \\
15.2 \\
14.5 \\
= \\
= \\
14.8 \\
13.7\end{array}$ & $\begin{array}{l}14.5 \\
14.8 \\
14 \cdot 7 \\
16.2 \\
12 \cdot 7 \\
14 \cdot 8 \\
14 \cdot 6 \\
15 \cdot 6 \\
13.4 \\
14 \cdot 7 \\
14 \cdot 3 \\
12 \cdot 8 \\
14.5 \\
15.0\end{array}$ & 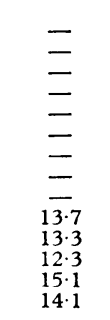 & $\begin{array}{l}= \\
= \\
= \\
\bar{z} \\
\overline{-} \\
14 \cdot 4 \\
14.7 \\
12.5 \\
14.5 \\
14.5\end{array}$ & $\begin{array}{l}= \\
\bar{Z} \\
\overline{ } \\
\overline{ } \\
\overline{14.9} \\
14.2 \\
11.6 \\
14.3 \\
14.9\end{array}$ & $\begin{array}{l}\text { leucodystrophy } \\
\text { M.S.; ACTH } 2 \text { weeks } \\
\text { Anoxic cerebral damage } \\
\text { M.S., chronic, } 1961 \\
\text { Vascular cerebral damage } \\
\text { Vascular cerebral damage-hemiplegia } \\
\text { Dementia } \\
\text { M.S.; } 3 \text { days ACTH, Feb. } 1971 \\
\text { Dementia; large venticles } \\
\text { M.S.; ACTH } 2 \text { weeks } \\
\text { M.S., 1 year } \\
\text { M.S., 8 years, chronic } \\
\text { M.S., } 8 \text { years, chronic } \\
\text { Cerebellar degeneration } \\
\text { C.N.S. degeneration }\end{array}$ \\
\hline
\end{tabular}


as other neuropharmacologically active substances, as described previously for brain E.F. (Field, Caspary, and Carnegie, 1971). In these experiments the blocking agent-for example, serotonin-was introduced into the lymphocyte-macrophage mixture and incubation carried out for 30 minutes at $20^{\circ} \mathrm{C}$ before antigen was added and the incubation then continued for 60 to 90 minutes. As control, antigen was introduced first and after 60 minutes the blocking agent was added. In the present series of experiments serotonin, adrenaline, acetylcholine. tryptamine, and histamine have been evaluated as blocking agents. In principle the experiment examines how far the "blocking agent" can enter into successful competition with antigen (E.F. or tumour antigen) in attachment to the sensitive sites on lymphocytes.

\section{Results}

Lymphocytes from patients with malignant neoplasia generally produce a 15 to $20 \%$ macrophage speed reduction with brain E.F. used as antigen (Field and Caspary, 1970) as compared with less than $5 \%$ in normal subjects. (Those in the laboratory who habitually work with brain (either in making E.F. or injecting it with Freund's adjuvant into experimental animals) may give values as high as $10 \%$. One guest worker's value has more than doubled in six months to $5 \cdot 3 \%$. However, the

TABLE II-Blockage by Drugs

\section{Patient I (Man aged 67)-Carcinoma of Bronchus}

E.F.

Carcinoma vulva basic protein Carcinoma breast 1

Serotonin + carcinoma breast 1 Carcinoma breast 1 + serotonin Acetylcholine + carcinoma breast 1 Carcinoma breast 1 +acetylcholine Carcinoma breast Serotonin + carcinoma breast 2 Carcinoma breast $2+$ serotonin Carcinoma breast 2 + acetylcholine

Patient II (Woman aged 55)-Carcinoma of Cervix

E.F.

Serotonin + E.F.

Carcinoma vulva basic protein

Serotonin + carcinoma vulva

Adrenaline + carcinomanin

Adretylcholine + carcinoma vulva

Tryptamine + carcinoma vulva

Histamine + carcinoma vulva

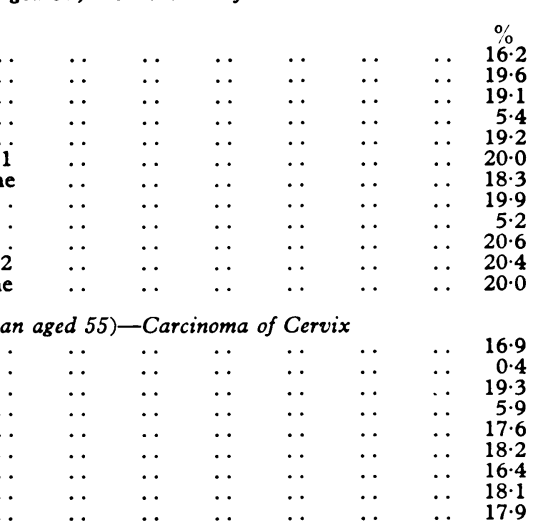

TABLE IV-Reproduction of Four lines of an Original Protocol showing the Actual Measurements Made and Their Statistical Treatment

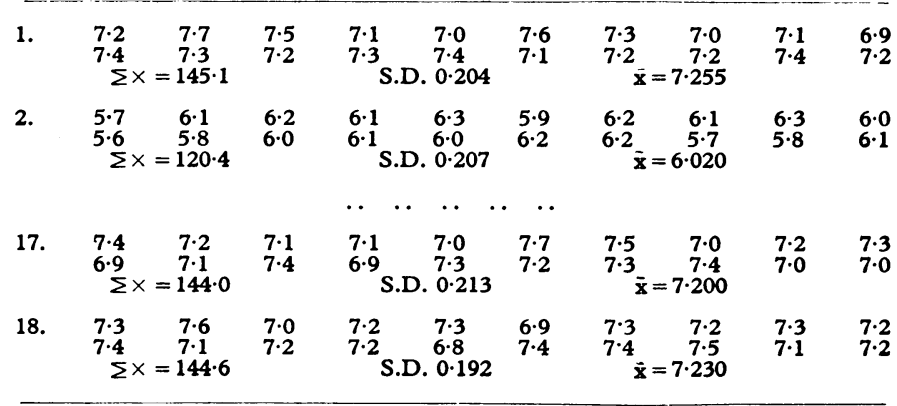

presence of circulating sensitized lymphocytes is not of itself a sufficient cause of experimental allergic encephalomyelitis in monkeys (Caspary and Field, 1971).) When tumour basic protein (carcinoma of vulva, carcinoma of breast 1 , carcinoma of breast 2, carcinoma of lung, carcinoma of stomach, lymphosarcoma) was substituted for brain E.F., comparable reductions were obtained. Indeed as shown in Table $I$ in every patient with malignant neoplasia the percentage reduction produced with cancer basic protein exceeded that with brain E.F. While the difference in individual cases was not always statistically significant, the grouped results from the use of the basic proteins are very significantly different. In the few cases where it has been possible to study the same patient with basic protein samples derived from different human tumours, the values have been remarkably consistent among themselves and higher than those for brain E.F. (Table I). There was no dependence on the type of human malignant tumour from which the basic protein was prepared.

On the other hand in the case of patients with destructive central nervous system lesions brain E.F. gave consistently higher results than tumour "E.F."-that is, the reverse of what was found in malignant neoplasia (Table I).

When an attempt is made to block the interaction of tumour basic protein with lymphocytes by means of serotonin the blockage achieved is incomplete (Table II). Thus in the case of breast cancer 1 serotonin reduced the value from 19.1 to $5.4 \%$ with carcinoma breast 2 antigen from 19.9 to $5 \cdot 2 \%$. Other "nervous active" drugs such as acetylcholine, noradrenaline, etc., have no effect. The effects with a few miscellaneous subjects are shown in Table III. A complete protocol is given in Table IV and the unscrambled results in Table V.

TABLE III-Selection of Miscellaneous Subjects

\begin{tabular}{|c|c|c|c|c|c|c|c|c|c|c|c|}
\hline Subject & Sex & Age & E.F.1 & E.F.2 & Ca. Breast 1 & Ca. Breast 2 & Ca. Lung & Ca. Stomach & $\begin{array}{l}\text { Lympho- } \\
\text { sarcoma }\end{array}$ & Ca. Vulva & Status \\
\hline $\begin{array}{c}{ }^{*} \mathrm{~A} \\
\mathrm{~B} \\
\mathrm{C} \\
+\mathrm{D} \\
\mathrm{D} \\
\mathrm{F} \\
\mathrm{G} \\
\mathrm{G} \\
{ }^{*} \mathrm{H} \\
{ }^{*} \mathrm{I} \\
\mathrm{J} \\
\mathrm{K} \\
\mathrm{L} \\
\mathrm{M} \\
\mathrm{N} \\
\mathrm{O} \\
\mathrm{P} \\
\mathrm{Q} \\
\mathrm{R} \\
\mathrm{S}\end{array}$ & $\begin{array}{l}\text { M. } \\
\text { F. } \\
\text { M. } \\
\text { M. } \\
\text { F. } \\
\text { M. } \\
\text { M. } \\
\text { F. } \\
\text { M. } \\
\text { M. } \\
\text { F. } \\
\text { F. } \\
\text { F. } \\
\text { M. } \\
\text { F. } \\
\text { F. } \\
\text { M. } \\
\text { M. } \\
\text { F. }\end{array}$ & $\begin{array}{l}34 \\
24 \\
36 \\
34 \\
27 \\
33 \\
28 \\
39 \\
56 \\
44 \\
23 \\
75 \\
87 \\
43 \\
19 \\
19 \\
48 \\
53 \\
74\end{array}$ & $\begin{array}{c}8.1 \\
1.5 \\
\frac{5.3}{-1} \\
0.8 \\
10.2 \\
5.7 \\
2.2 \\
2.9 \\
2.4 \\
5.4 \\
1.4 \\
0.4 \\
6.6 \\
1.5 \\
5.1\end{array}$ & $\begin{array}{c}\bar{Z} \\
7.9 \\
0.8 \\
\overline{1.3} \\
10.5 \\
\frac{1}{1.7} \\
3.4 \\
3.1 \\
5.8 \\
= \\
= \\
2.7 \\
5.2\end{array}$ & 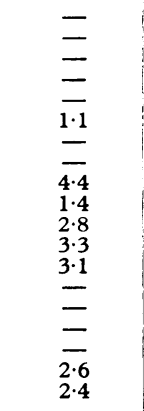 & $\begin{array}{l}\overline{1.5} \\
= \\
= \\
\overline{7.3} \\
\bar{Z} \\
= \\
= \\
\bar{Z} \\
2.5 \\
1.8\end{array}$ & 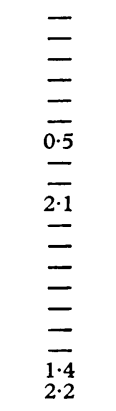 & 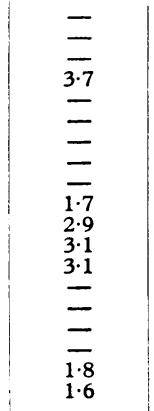 & $\begin{array}{l}\bar{Z} \\
\bar{Z} \cdot 3 \\
\bar{Z} \\
\bar{z} \\
1.4 \\
3.3 \\
2 \cdot 8 \\
3.2 \\
\bar{Z} \\
\bar{Z} \\
2.3\end{array}$ & $\begin{array}{l}4.1 \\
二 \\
1.9 \\
\overline{1} \\
8.4 \\
\overline{1} \cdot 9 \\
2.5 \\
3.8 \\
3.5 \\
4.9 \\
0.1 \\
0.9 \\
5.8 \\
3.2 \\
2.1\end{array}$ & $\begin{array}{l}\text { Normal } \\
\text { Normal } \\
\text { Normal } \\
\text { Normal } \\
\text { Normal } \\
\text { Normal } \\
\text { Normal } \\
\text { Normal } \\
\text { Normal } \\
\text { Normal } \\
\text { Normal } \\
\text { Normal } \\
\text { Normal } \\
\text { Normal } \\
\text { Normal } \\
\text { Fibroadenoma of breast } \\
\text { Cirrhosis of liver } \\
\text { Chronic bronchitis } \\
\text { Chronic bronchitis }\end{array}$ \\
\hline
\end{tabular}

- Laboratory workers regularly exposed to E.F.

+ Guest worker whose result has doubled in six months. 
TABLE v-Results shown in Table IV Unscrambled

\begin{tabular}{|c|c|c|c|c|c|c|c|c|}
\hline Patient & Sex & Age & Diagnosis & No.* & Antigen & $\begin{array}{l}\text { Migration Time } \\
\text { + S.D. }\end{array}$ & $\begin{array}{l}\text { Increase in Migration Time } \\
\text { Compared with Control }\left({ }_{0}^{\circ}\right)\end{array}$ & $\mathrm{P}+$ \\
\hline $\mathrm{x}$ & M. & 49 & M.S. 1 year & $\begin{array}{r}10 \\
13 \\
3 \\
8 \\
6 \\
11\end{array}$ & $\begin{array}{l}\text { CON. } \neq \\
\text { E.F. } \\
\text { Ca. breast } \\
\text { Ca. stomach } \\
\text { Ca. lung } \\
\text { Lymphosarcoma }\end{array}$ & $\begin{array}{l}6.005 \pm 0.176 \\
7.340 \pm 0.241 \\
6.890 \pm 0.189 \\
6.825 \pm 0.229 \\
6.870 \pm 0.229 \\
6.900 \pm 0.162\end{array}$ & $\begin{array}{l}20 \cdot 6 \\
14 \cdot 7 \\
13 \cdot 7 \\
14 \cdot 4 \\
14 \cdot 9\end{array}$ & $\begin{array}{l}0.001 \\
0.001 \\
0.001 \\
0.001\end{array}$ \\
\hline $\mathbf{Y}$ & F. & 49 & $\begin{array}{l}\text { Follicular lymphoma } \\
2 \text { months }\end{array}$ & $\begin{array}{r}2 \\
12 \\
9 \\
15 \\
18 \\
4\end{array}$ & $\begin{array}{l}\text { CON. } \\
\text { E.F. } \\
\text { Ca. breast } \\
\text { Ca. stomach } \\
\text { Ca. lung } \\
\text { Lymphosarcoma }\end{array}$ & $\begin{array}{l}6.020 \pm 0.207 \\
6.935 \pm 0.223 \\
7 \cdot 255 \pm 0.216 \\
7 \cdot 205 \pm 0.252 \\
7 \cdot 230 \pm 0.192 \\
7 \cdot 265 \pm 0.232\end{array}$ & $\begin{array}{l}15 \cdot 2 \\
20 \cdot 5 \\
19 \cdot 7 \\
20 \cdot 1 \\
20 \cdot 7\end{array}$ & $\begin{array}{l}0.001 \\
0.001 \\
0.001 \\
0.001\end{array}$ \\
\hline $\mathrm{z}$ & F. & 63 & $\begin{array}{l}\text { Ca. breast } \\
\text { Mastectomy } 8 \text { years ago }\end{array}$ & $\begin{array}{r}7 \\
5 \\
14 \\
16 \\
1 \\
17\end{array}$ & $\begin{array}{l}\text { CON. } \\
\text { E.F. } \\
\text { Ca. breast } \\
\text { Ca. stomach } \\
\text { Ca. lung } \\
\text { Lymphosarcoma }\end{array}$ & $\begin{array}{l}6.005 \pm 0.209 \\
6.960 \pm 0.193 \\
7 \cdot 170 \pm 0.181 \\
7 \cdot 250 \pm 0.209 \\
7 \cdot 255 \pm 0.204 \\
7 \cdot 200 \pm 0.213\end{array}$ & $\begin{array}{l}15 \cdot 9 \\
19 \cdot 4 \\
20 \cdot 7 \\
20 \cdot 8 \\
19 \cdot 9\end{array}$ & $\begin{array}{c}0.005-0.001 \\
0.001 \\
0.001 \\
0.001\end{array}$ \\
\hline
\end{tabular}

- Number of tube specimens as scrambled and studied "blind." † Difference of cancer antigen result from E.F. result. $\quad \ddagger$ Macrophages with lymphocytes without antigen.

\section{Discussion}

The results confirm the expectation that an E.F.-like antigen is present in tumour tissue to which presumably lymphocytes become sensitized. This antigen appears to be similar, whatever the source of the (human) tumour, so far as its effectiveness in the cytopherometric test is concerned. It is a significantly better antigen in the cancer test than brain E.F. Basic protein derived from human brain, on the other hand, is a more effective antigen when lymphocytes from patients with destructive disease of the nervous system are under test. While E.F. from brain (when mixed with Freund's complete adjuvant) is highly encephalitogenic in guinea-pigs (Caspary and Field, 1965) that from tumours (even in $100-\mu \mathrm{g}$ doses) is not. It is known that the encephalitogenic determinant of synthetic peptide (Westall, Robinson, Caccam, Jackson, and Eylar, 1971 ) is centred on tryptophan, and it would seem likely that the biological differences are a reflection of minor variation in amino-acid sequence on either side of tryptophan. Further study of these sequences is in progress in collaboration with Dr. P. R. Carnegie.

Following the suggestion by Carnegie (1971) that serotonin had a molecular configuration complementary to the antigenic determinant of human brain E.F., Field et al. (1971) showed that serotonin is able to block the interaction of E.F. with sensitized lymphocytes almost completely, while blocking of reaction with cancer antigens is incomplete-that is, the fit of serotonin to brain E.F. is better than to cancer antigens.

The effect of serotonin in blocking tumour basic protein is less than in blocking E.F. from brain. This suggests that the "fit" of serotonin to E.F. is better than to the antigens of tumour (Field et al., 1971).

The close approximation of the results obtained with all the tumour antigens studied is of interest and suggests that they have a common determinant. Attempts are being made to characterize it and to raise sera specific to it. In no case in the present small series has there been any departure from the rule that brain E.F. gives higher results than tumour basic protein in patients with degeneration of nervous parenchyma, and that the reverse is true in malignant neoplasia. The difference in nearly all cases is significant $(P<0.01)$. In our first report (Field and Caspary, 1970) no means were available of distinguishing between a positive result due to brain destruction and malignant neoplasia. The present work suggests that a distinction may be possible on the basis of reaction with both brain E.F. and tumour basic protein. Only further tests will show how reliable the difference is in individual cases. It would be indeed remarkable if, in a biological test of this character, success rate was total and problem cases did not arise. These can be anticipated, especially among older people who have some degree of cerebral vascular degeneration. Since so much investigation of cancer cell biochemistry in the past has pointed to an essential similarity with normal cells, experiments are being carried out with basic protein extracted from normal tissues. To consider this in detail here would be outside the scope of the present work but it would seem that a new antigenic determinant appears on the surface of the cancer cell, and this is similar in all malignant tumours.

The E.F. extracted from brain is made from a normal human tissue and differs from the basic protein made from tumours in that it is a "less effective" antigen in the test-no doubt related to its lesser "goodness of fit" to the tumour-sensitized lymphocyte. Indeed the actual figures obtained with tumour antigens of different provenance are remarkably similar. To this extent all the tumours tested may be deemed to have a common antigen. There would seem to be no clearly separate antigen unrelated to normal tissue present in cancer. Had there been, it would have been discovered long ago. But what is extractable from tumour, while similar to that obtained from normal tissue, is sufficiently different to act as a much better antigen in the cancer test. Indeed the cancer "antigen" is probably the result of some molecular rearrangement or perhaps amino-acid sequence difference in the surface of the cancer cell. The difference from normal is a subtle one, brought out by the tell-tale lymphocyte sensitization for which the technique described is a sensitive test. It is tempting to speculate whether this surface difference may be associated with the loss of contact inhibition so characteristic of cancer cells.

Finally, the present work suggests that a common antigen may be present in human malignant growths manifesting itself by specific lymphocyte sensitization, and some evidence for specificity has recently been offered by Field et al. (1971) from a study of serotonin blocking of the antigen. The study of lymphocyte sensitization gives encouragingly consistent results when compared with the mass of data derived from circulating antibody studies reviewed by Southam (1967). It underlines, too, Klein's (1967, 1970) comment that disproportionately little attention has been devoted to cellular immunity phenomena in malignant disease.

We would like to thank numerous medical and surgical colleagues at both the Royal Victoria Infirmary and the Newcastle General Hospital who gave us ready access to patients under their care. We also thank Mr. S. Way, Mr. J. D. Rose, Mr. D. F. Hindmarsh, Mr. Ross Taylor, and Mr. R. Dobson for supplying us with tumour material removed at operation. To Mr. A. Keith and Mrs. J. Cunningham we are indebted for technical help in the preparation of macrophages and lymphocytes. Dr. P. R. Carnegie made E.F.2 and also extracted antigen from carcinoma of stomach. 


\section{References}

Carnegie, P. R. (1971). Nature, 229, 25

Caspary, E. A. (1971). Nature New Biology, 231, 24.

Caspary, E. A., and Field, E. J. (1965). Annals of the New York Academy of Science, 122, 182.

Caspary, E. A., and Field, E. J. (1971). European Neurology, 4, 257.

Field, E. J. and Caspary,.E. A. (1970). Lancet, 2, 1337.
Field, E. J., and Caspary, E. A. (1971). Fournal of Clinical Pathology, 24, 179 Field, E. J., Caspary, E. A., and Carnegie, P. R. (1971). Nature. In press. Field, E. J., Caspary, E. A., and Carnegie, P. R. (1971). Nature. In press. Klein, G. (1970). British Medical fournal, 4, 418.

Klein, G. (1967). In Specific Tumour Antigens; Symposium, ed. R. J. C. Harris, p. 364. Copenhagen, Munksgaard.

Southam, C. M. (1967). Progress in Experimental Tumour Research, 9, 1.

Westall, F. C., Robinson, A. B., Caccam, J., Jackson, J., and Eylar, E. H. (1971). Nature, 229, 22.

\title{
Fatal Fat Embolism following Replacement Arthroplasty for Transcervical Fractures of Femur
}

\author{
G. A. GRESHAM, A. KUCZYǸSKI, D. ROSBOROUGH
}

British Medical fournal, 1971, 2, 617-619

\begin{abstract}
Summary
Seven cases are reported of death in old people associated with transcervical fractures of the femur and occurring shortly after insertion of a Thompson prosthesis. They are compared with six fatalities following similar injury but not surgically treated and with three which followed internal fixation. Positive controls for massive fat embolism were selected from fatal cases of multiple and severe skeletal fractures due to road accidents.

It seems likely that patients undergoing this operation are peculiarly susceptible to lethal fat embolism. The clinical features, diagnosis, pathological aspects, and prevention of fat embolism are discussed.
\end{abstract}

\section{Introduction}

Fat embolism is a well-recognized complication of all major fractures. Wilson and Salisbury (1944) found a 5\% mortality among 119 fractured long bones in battle casualties from this cause. Postmortem studies after traumatic deaths have shown a high incidence of severe fatal fat embolism $-20 \%$ by Vance (1931) and 33\% by Robb-Smith (1941). Sevitt (1966) reported that $90-100 \%$ of people dying after injury show varying degrees of pulmonary fat embolism.

As a clinical problem fat embolism has been mentioned only rarely after transcervical fractures in the elderly. A review of replacement arthroplasty, carried out under the auspices of the American Orthopaedic Association, makes no mention of the problem (Reynolds, 1958). Vanderwater (1961) reported the case of an elderly patient with a transcervical fracture of the femur who died under a general anaesthetic from this cause, but no details are given. Sporadic reports have recently appeared in the medical literature (Burgess, 1970; Gresham and Kuczyǹski, 1970; Harris, 1970; Hyland and Robins, 1970).

Clinical distinction between sequelae of fat or thrombotic embolization and old age is difficult: confusion, tachycardia, and faecal or urinary incontinence are common to both states. It is not sufficiently appreciated how often pulmonary embolization in the elderly produces psychiatric or neurological

\section{Cambridge University}

G. A. GRESHAM, M.D., M.R.C.PATH., Morbid Anatomist

A. KUCZYÑSKI, M.B., B.s., Wellcome Research Fellow in Biochemistry

Ipswich Group of Hospitals

D. ROSBOROUGH, F.R.C.s., Consultant Orthopaedic Surgeon symptoms and signs (Fred et al., 1967). Petechiae, a diagnostic feature, appear relatively late and inconstantly in the diathesis.

A prospective seven-month study of all deaths (in our group of hospitals) associated with fractures of the femoral neck and elective hip operations was therefore arranged.

\section{Patients, Materials, and Methods}

During the period of study 110 patients were admitted with fractures of the upper end of the femur (Table I). All who died (16) in this time were brought to thorough necropsy. Sections for histological examination were taken as indicated, but in all cases included thick $(10 \mu)$ frozen preparations of lungs, kidney, and brain, which were stained with haematoxylin and eosin and Scharlach R. Seven (Table II) had undergone prosthetic replacement of the hip (Thompson's); three (Table III) had had internal fixation by nail-plate; and six, owing to their poor condition, had had no surgical procedures whatever (Table III).

TABLE I-Treatment of Femoral Neck Fractures admitted during the Period of Study

\begin{tabular}{|c|c|c|c|}
\hline \multirow{2}{*}{\multicolumn{2}{|c|}{ Treatment }} & \multicolumn{2}{|c|}{ Fractures } \\
\hline & & Intertrochanteric & Transcervical \\
\hline 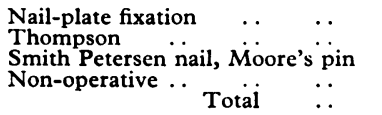 & $\begin{array}{l}\cdots \\
\cdots \\
\cdots \\
\cdots\end{array}$ & $\begin{array}{l}45(3) \\
\overline{1} \\
56(3)\end{array}$ & $\begin{array}{l}55 \\
32(7) \\
8^{*} \\
9(3) \\
54(10)\end{array}$ \\
\hline
\end{tabular}

Numbers in parentheses are of deaths during period in hospital.

*Two patients had Thompson's arthroplasty later.

TABLE III-Clinicopathological Features of Deaths following Conservative and Internal-fixation Procedures

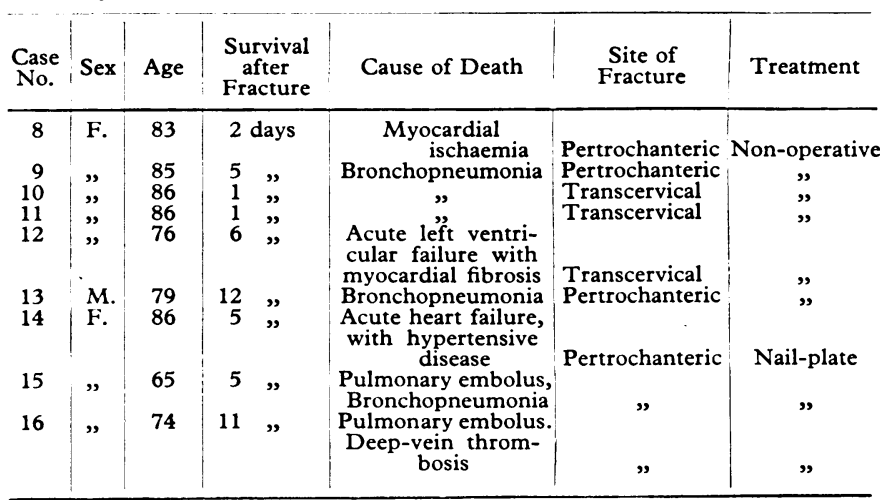

